Journal of Agritech Science, Vol 5 No 2, November 2021

\title{
RESPON PERTUMBUHAN DAN PRODUKSI TANAMAN BAWANG MERAH (Allium cepa L.) DENGAN APLIKASI PUPUK ORGANIK AGRODYKE DAN ZEOLIT
}

(Response of growth and production of onion (allium cepa l.) with organic fertilizer agrodyke and zeolite application)

\author{
Abri $^{1}$, A.F. Alhijasi ${ }^{2}$, Amirudin ${ }^{3}$ \\ 1,2,3 Universitas Bosowa Makassar, Fakultas Pertanian, Program Studi Agroteknologi, \\ Jl Urip Sumoharjo KM.4, Kota Makassar, Provinsi Sulawesi Selatan, \\ Kode Pos 90231, Email: amirudinunibos@gmail.com
}

\begin{abstract}
ABSTRAK
Penelitian ini bertujuan untuk mengetahui perbedaan pertumbuhan dan produksi tanaman bawang merah (Allium cepa L.) dengan aplikasi pupuk organik agrodyke dan zeolit. Penelitian Ini dilaksanakan di Kebun Bosowa Agro Desa Bontoramba, Kecamatan Pallangga, Kabupaten Gowa, Sulawesi Selatan yang dilaksanakan pada bulan Mei sampai dengan bulan Juli 2021. Metode penelitian yang digunakan adalah rancangan faktorial 2 faktor dalam kelompok, faktor pertama adalah aplikasi pupuk agrodyke yang terdiri dari A0 (kontrol), A1 (2 gr/l), A2 (4 gr/l), dan A3 (6 gr/l). Sedangkan faktor kedua terdiri dari Z0 (kontrol), Z1 (8000 $\mathrm{kg} / \mathrm{ha}), \mathrm{Z2}$ (10000 kg/ha), dan Z3 (12000 kg/ha). Masing-masing perlakuan diulang 3 kali sehingga jumlah keseluruhannya 48 satuan percobaan dengan jumlah tanaman setiap satuan percobaan sebanyak 20 tanaman, sehingga jumlah keseluruhan sebanyak 960 tanaman. Hasil penelitian menunjukkan bahwa respon terbaik pertumbuhan dan produksi tanaman bawang merah (Allium cepa L) terhadap aplikasi pemberian pupuk organik agrodyke pada dosis A2 (4 g/l air) dan A3 (6 g/l air) dan aplikasi pemberian zeolit pada dosis Z3 (12000 kg/ha), sedangkan intraksi kombinasi terbaik pertumbuhan dan produksi tanaman bawang merah (Allium cepa $\mathrm{L}$ ) terhadap aplikasi pemberian pupuk organik agrodyke dan zeolit pada dosis A3Z0 (6 g/l air + kontrol).
\end{abstract}

Kata kunci : Tanaman bawang merah (Allium cepa L.), pupuk agrodyke dan zeolit.

\begin{abstract}
This study aimed to determine the differences in the growth and production of shallot (Allium cepa L.) with the application of agrodyke and zeolite organic fertilizers. This research was carried out at Bosowa Agro Gardens, Bontoramba Village, Pallangga District, Gowa Regency, South Sulawesi which was carried out from May to July 2021. The research method used was a factorial design of 2 factors in groups, the first factor was the application of agrodyke fertilizer consisting of A0 (control), A1 (2 gr/l), A2 (4 gr/l), and A3 (6 gr/l). While the second factor consisted of Z0 (control), Z1 (8000 kg/ha), Z2 (10000 kg/ha), and Z3 (12000 kg/ha). Each treatment was repeated 3 times so that the total number of experimental units was 48 with the number of plants per experimental unit was 20 plants, so that the total number of plants was 960 plants. The results showed that
\end{abstract}


the best response to growth and production of shallot (Allium cepa L) was application of agrodyke organic fertilizer at doses of A2 (4 g/l water) and A3 (6 $\mathrm{g} / \mathrm{l}$ water) and application of zeolite at dose Z3 ( $12000 \mathrm{~kg} / \mathrm{ha}$ ), while the best combination of growth and production of shallot (Allium cepa L) was applied to the application of agrodyke and zeolite organic fertilizers at a dose of A3Z0 (6 g/l water + control).

Keywords: shallot (Allium cepa L.); agrodyke fertilizer; zeolite.

\section{LATAR BELAKANG}

Bawang merah (Allium cepa

L) merupakan sayuran semusim yang menempati posisi pertama sebagai komoditas unggulan sayuran di Indonesia. Bawang merah juga memiliki banyak manfaat antara lain sebagai obat alami seperti obat batuk (obat batuk berdahak), sesak napas, demam, masuk angin, dan menambah nafsu makan (Rahayu et $a l, 2018)$.

Produksi bawang merah di Sulawesi Selatan dari tahun 2015 sampai tahun 2017 mengalami kenaikan dalam skala nasional. Pada tahun 2015 produksi bawang merah sebanyak 69.889 ton, berikutnya tahun 2016 menjadi 96.256 ton, dan pada tahun 2017 menjadi 129.181 ton. Sempat mengalami penurunan Pada tahun 2018 menjadi 92.392 ton lalu naik kembali menjadi 101.762 ton pada tahun 2019 (BPS, 2019). Bawang merah menjadi penyumbang devisa terbesar dari sayuran semusim pada tahun 2018 dengan jumlah 5,22 ton dan nilai Free On Board (FOB) sebesar 6,29 juta US \$ ( Kementan 2018). Hal ini yang menjadi peluang untuk terus meningkatkan produksi bawang merah baik untuk memenuhi kebutuhan dalam negeri maupun untuk meningkatkan ekspor keluar negeri.

Salah satu aspek penting dalam budidaya tanaman bawang merah adalah penggunaan pupuk kimia secara berlebihan dan tidak berkelanjutan, disisi lain dapat meningkatkan produksi bawang merah namun dapat merusak kesuburan dan kesehatan tanah jika dilakukan secara terus menerus dengan takaran yang tinggi, tanpa mempertimbangkan kebutuhan tanaman dan ketersediaan hara dalam tanah yang dapat menyebabkan: (a) penimbunan hara, umumnya $P$ dalam tanah, (b) terkurasnya hara mikro dari tanah yang tidak pernah diberikan melalui pupuk, (c) terganggunya keseimbangan hara 
dalam tanaman, (d) lebih pekanya tanaman terhadap serangan hama dan penyakit, (e) terganggunya perkembangbiakan jasad renik yang menguntungkan dalam tanah, dan bahkan (f) terjadinya pencemaran lingkungan oleh unsur nitrat dari residu pupuk N. Kondisi ini akhirnya berakibat terhadap menurunnya produktivitas lahan, tidak efisiennya penggunaan input serta menurunnya kualitas lingkungan (Soepardi, 1983; Hafsah, 2003).

Selain itu, kurangnya penggunaan bahan organik dan intensifnya pemberian pupuk kimia telah menyebabkan kandungan bahan organik tanah menurun baik jumlah maupun kualitasnya, tanah menjadi kompak, kerusakan struktur tanah, aerasi tanah berkurang, dimana kondisi ini menurunkan kemampuan tanah dalam menyimpan dan melepaskan hara dan air bagi tanaman dan menurunkan produktivitas lahan.

Berdasarkan dampak negatif penggunaan pupuk kimia, maka perlu diupayakan penggunaan bahan organik secara bertahap guna mensubtitusi penggunaan pupuk kimia (anorganik). Salah satu sumber pupuk organik adalah limbah pertanian dan ternak, namun bahan tersebut dapat menjadi ancaman karena mencemari lingkungan dan sekaligus potensial jika dimanfaatkan sebagai bahan penambah kesuburan tanah melalui proses alami dalam menyediakan unsur hara bagi tanaman. Di samping itu, bahan organik alami seperti pupuk kandang mengalami proses dekomposisi yang cukup lama (4-6 minggu) sehingga tidak optimal dalam pemanfaatannya sebagai pupuk untuk bawang merah yang berumur pendek. Oleh karena itu perlu diupayakan pemanfaatan pupuk organik yang sudah jadi yang sudah banyak diproduksi dan beredar di pasaran.

Pupuk agrodyke merupakan salah satu jenis pupuk organik, serbaguna terlengkap dan ramah lingkungan dan mengandung unsur hara mikro dan makro instan. Pemberian pupuk agrodyke berpengaruh nyata terhadap tinggi tanaman mahoni umur 40, 60 dan 80 HSP karena konnsentrasi pupuk agrodyke yang diberikan tepat, diduga sesuai dengan kebutuhan unsur hara oleh tanaman sehingga pertambahan tinggi tanaman dapat berlangsung dengan baik. Pupuk agrodyke mampu melepas ikatan 
ion-ion unsur hara mineral liat yang terdapat pada lapisan di bawah permukaan tanah pada tanah seperti sawah atau di bawah permukaan tanah pada tanah tidak jenuh air secara proses kimiawi melalui mekanisme biometabolisme oleh mikroorganisme sehingga tanah menjadi gembur dan subur (Darmia, 2011). Dalam membantu menguraikan unsur- unsur yang terkandung di dalam pupuk organik agrodyke sehingga dengan mudah diserap oleh tanaman maka di perlukan pembenah tanah yang baik. Berbagai bahan pembenah tanah berupa hasil tambang telah banyak ditemukan di Indonesia, antara lain adalah zeolit.

Zeolit dapat digunakan untuk memperbaiki kesuburan aktual tanah dan dapat berperan sebagai bahan pembenah tanah. Di kalangan ahli tanah pembenah tanah dikenal sebagai soil conditioner seperti zeolit dan secara bersamaan diberi juga bahan organik diyakini mampu memperbaiki struktur tanah, dapat merubah kapasitas tanah menahan dan melalukan air, serta dapat memperbaiki kemampuan tanah memegang unsur hara, sehingga hara tidak mudah hilang, dan tanaman masih mampu memanfaatkannya sehingga produksi tanaman dapat tingkatkan.

Dari latar belakang tersebut diatas maka perlu dikaji bagaimanakah pengaruh pemberian pupuk organik agrodyke dan zeolite terhadap pertumbuhan dan produksi tanaman Bawang merah Serta pada dosis berapakah pupuk organik agrodyke dan zeolite ini dapat menghasilkan pertumbuhan dan bawang merah paling baik.

\section{Tujuan Penelitian}

Penelitian ini bertujuan untuk mengetahui dosis pupuk organik agrodyke dan zeolite yang tepat terhadap pertumbuhan dan produksi tanaman bawang merah, Serta kombinasi antara pupuk organik agrodyke dan zeolit yang tepat terhadap pertumbuhan dan produksi tanaman bawang merah

Kegunaan percobaan ini di harapkan dapat di jadikan sebagai bahan Informasi untuk budidaya tanaman bawang merah secara organik.

\section{Manfaat Penelitian}


Kegunaan percobaan ini di harapkan dapat di jadikan sebagai bahan Informasi untuk budidaya tanaman bawang merah secara organik.

\section{METODE PENELITIAN}

\section{Tempat dan Waktu penelitian}

Penelitian Ini dilaksanakan di

Kebun Bosowa Agro Desa Bontoramba, Kecamatan Pallangga, Kabupaten Gowa, Sulawesi Selatan pada bulan Mei sampai dengan bulan Juli 2021 .

\section{Bahan dan Alat}

Bahan yang di gunakan dalam penelitian ini antara lain : Benih Bawang merah Varietas Bima, Pupuk Agrodyke dan Zeolit.

Alat yang di gunakan dalam penelitian ini Cangkul, Timbangan Digital, Meteran, Jangka sorong digital, Sprayer, Alat tulis, Handphone (Dokumentasi).

\section{Metode Pengambilan Data}

Penelitian ini di lakukan dalam bentuk percobaan dan disusun menggunakan Rancangan faktorial 2 faktor.
Faktor pertama adalah aplikasi pupuk organik agrodyke yang terdiri dari :

A0 : kontrol

A1 : 2 gram/Liter air

A2 : 4 gram/Liter air

A3 : 6 gram/Liter air

Faktor kedua adalah aplikasi Zeolit yang terdiri dari :

Z0 : kontrol

$\mathrm{Z1}: 8000 \mathrm{~kg} / \mathrm{ha}$

$\mathrm{Z2}: 10.000 \mathrm{~kg} / \mathrm{ha}$

$\mathrm{Z3}: 12.000 \mathrm{~kg} / \mathrm{ha}$

\section{Pelaksaan Penelitian}

\section{Pengolahan lahan}

Pengolahan tanah dilakukan dengan traktor, tanah yang diolah hanya bagian atas (Top Soil) dengan kedalaman $\pm 20 \mathrm{~cm}$. Tanah didiamkan selama satu minggu.

\section{Pembuatan petak percobaan}

Setelah tanah diolah, dibuat 16 petak percobaan yang masingmasing diulang 3 kali sehingga terdapat 48 petak percobaan. Ukuran masing-masing petak percobaan 100 $\mathrm{cm} \times 80 \mathrm{~cm}$, jarak antar tanaman adalah $20 \times 20 \mathrm{~cm}$, jarak antar petak $50 \mathrm{~cm}$ sedangkan jarak antar ulangan $50 \mathrm{~cm}$. luas lahan yang digunakan adalah $96,90 \mathrm{~m}^{2}$.

\section{Aplikasi perlakuan}


JASc, Vol 5 No 2, November 2021

Tahap awal mempersiapkan zeolite. Diaplikasikan 1 minggu sebelum tanam, dengan cara ditebarkan secara merata sesuai perlakuan. Selanjutnya pemberian pupuk organik agrodyke yang dilarutkan kedalam air lalu diaplikasikan dengan cara disemprotkan langsung pada tanaman dan tanah sebanyak 3 kali, dengan interval waktu aplikasi 14 hari dimulai pada umur 7 hst, 21 hst, 35 hst, dan 49 hst.

\section{Penanaman}

Sebelum ditanam benih bawang merah dipilih yang diameter umbinya hampir sama. Umbi yang terpilih kemudian dipotong 1/3 bagian dari ujungnya untuk memecahkan masa dormansi dan mempercepat pertumbuhan tunas tanaman, kemudian benih bawang merah ditanam dengan membenamkan seluruh bagian umbi ke dalam tanah.

\section{Pemeliharaan}

$$
\text { Kegiatan pemeliharaan }
$$

meliputi penyulaman dan penjarangan, penyiangan, pemberantasan hama dan penyakit.

\section{Pemanenan}

Pemanenan dilakukan setelah tanaman bawang merah berumur 65 HST. Ciri ciri bawang merah siap panen adalah sebagian besar daun tanaman telah rebah dan jika dipegang pangkal daun sudah lemas, daun sudah berwarna kuning pucat sekitar $\quad 70-80 \%$. Umbi sudah berwarna merah tua atau keunguan dan berbau khas, kemudian sebagian umbi sudah terlihat dipermukaan tanah. Panen dilakukan dengan cara mencabutnya langsung secara harihati, lalu dibersihkan dari tanah.

\section{Komponen Pengamatan}

1. Tinggi tanaman $(\mathrm{cm})$

2. Jumlah daun

3. Jumlah Umbi

4. Diameter Umbi (mm)

5. Berat umbi basah (g)

6. Berat umbi kering (g)

\section{HASIL DAN PEMBAHASAN}

Hasil

\section{Tinggi Tanaman}

$$
\begin{aligned}
& \text { Hasil Analisis penelitian } \\
& \text { menunjukkan bahwa perlakuan } \\
& \text { pemberian berbagai kombinasi } \\
& \text { pupuk agrodyke dan zeolit tidak } \\
& \text { berpengaruh nyata terhadap tinggi } \\
& \text { tanaman Bawang merah pada umur } \\
& 15 \text { dan } 30 \text { hst, sedangkan kombinasi }
\end{aligned}
$$


pupuk agrodyke dan zeolit berpengaruh nyata terhadap tinggi tanaman Bawang merah pada umur 45 Hst. Analisis uji lanjutan BNT $\alpha=0,05$ pada umur 45 hst menunjukkan bahwa terjadi interaksi antara pengaruh pemberian berbagai kombinasi pupuk agrodyke dan zeolite terhadap tinggi tanaman.

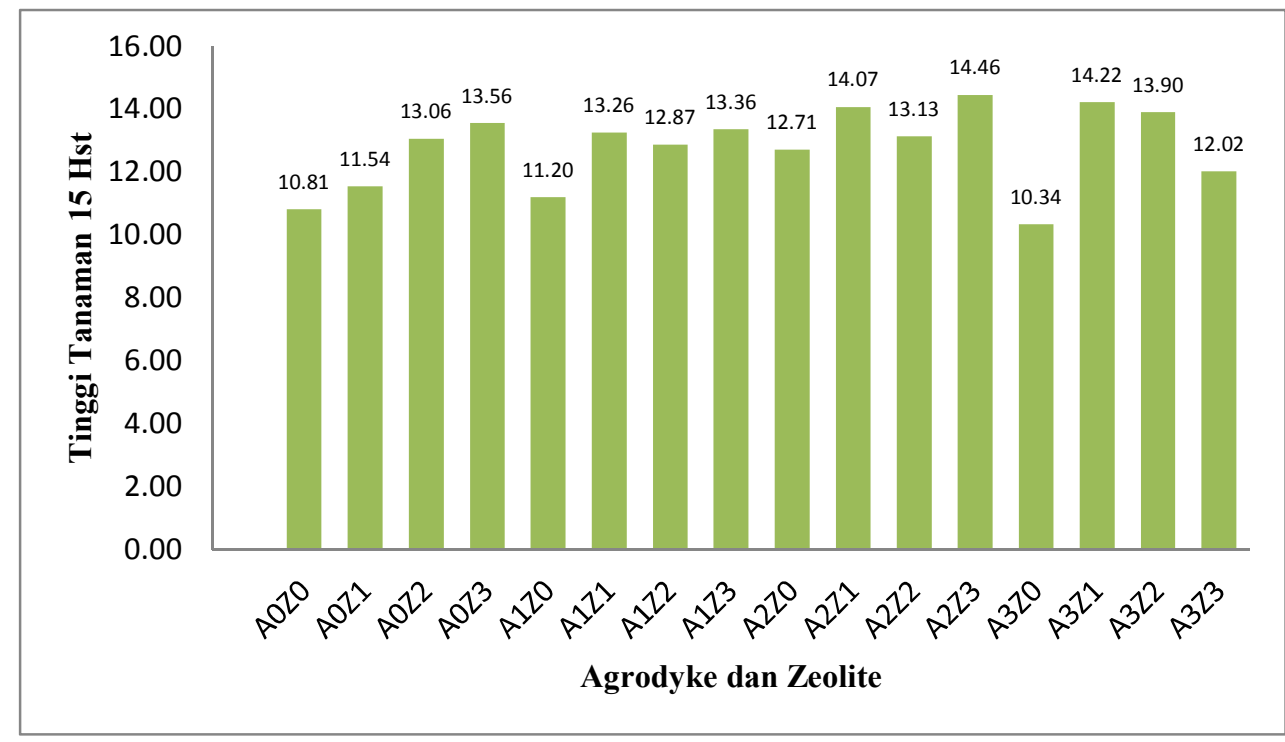

Gambar 1. Rata-Rata tinggi tanaman bawang merah 15 hst

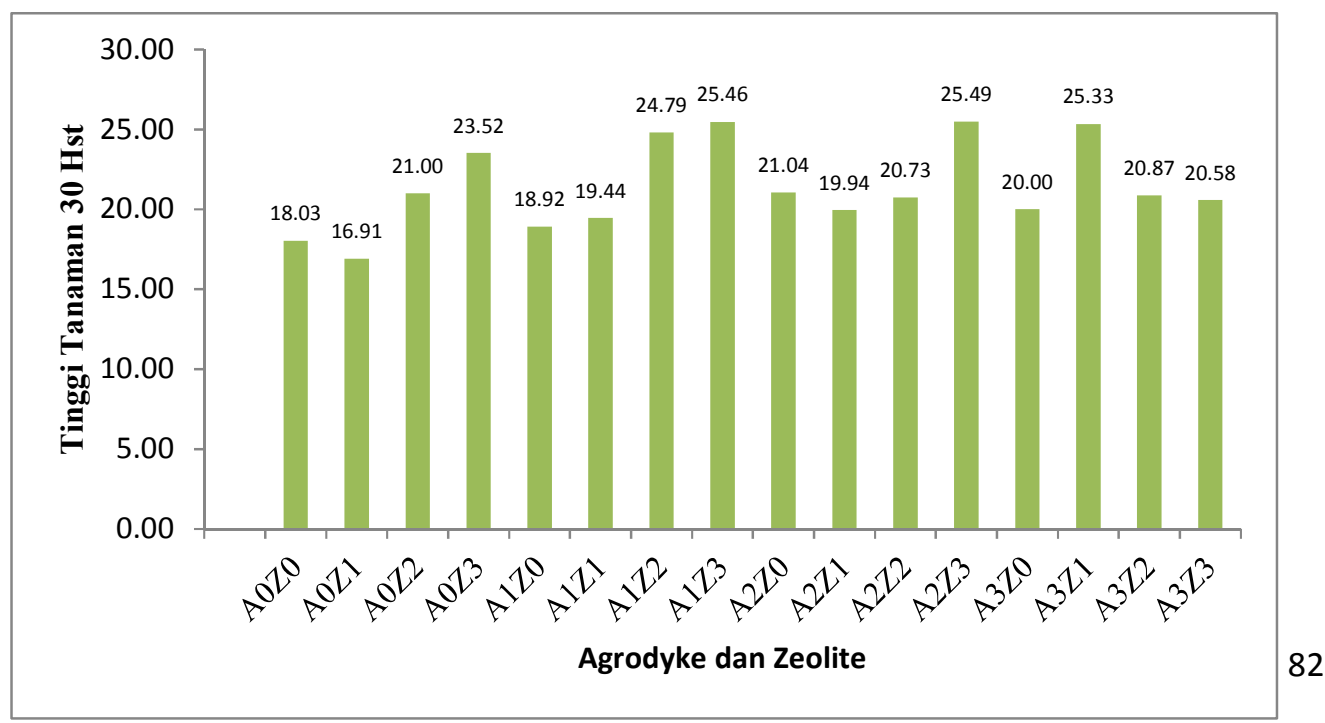


Gambar 2. Rata-Rata Tinggi Tanaman Bawang Merah 30 hst

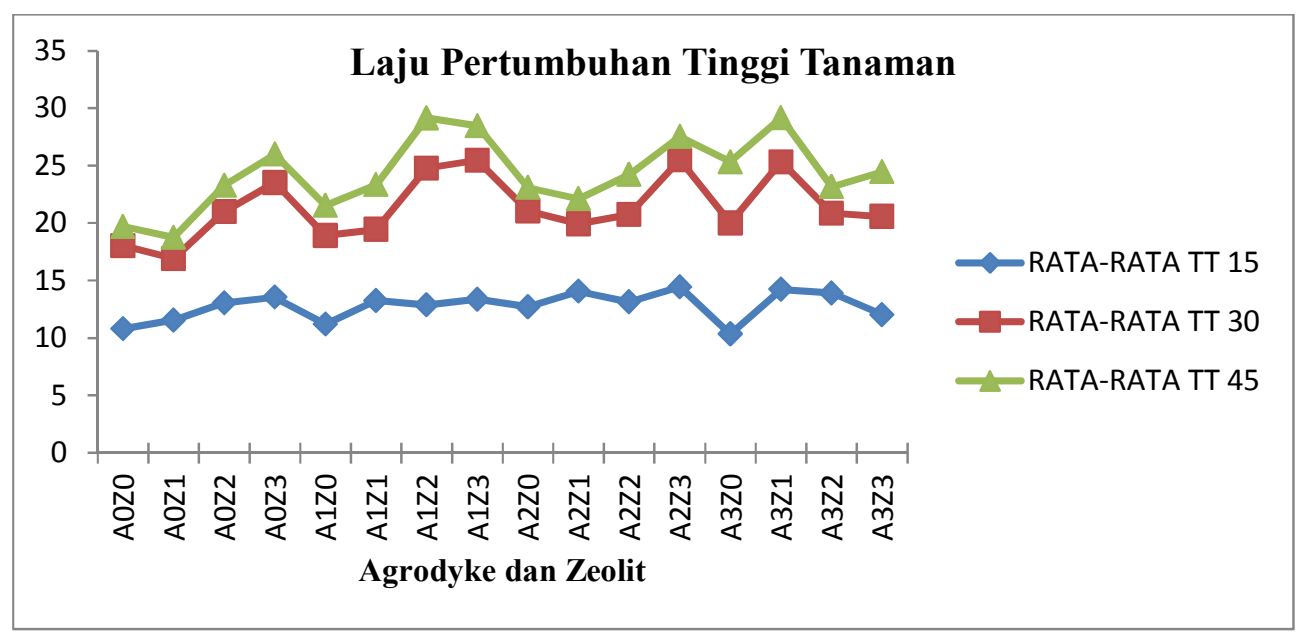

Gambar 3. Laju pertumbuhan tinggi tanaman bawang merah pada pemberian kombinasi pupuk agrodyke dan zeolit

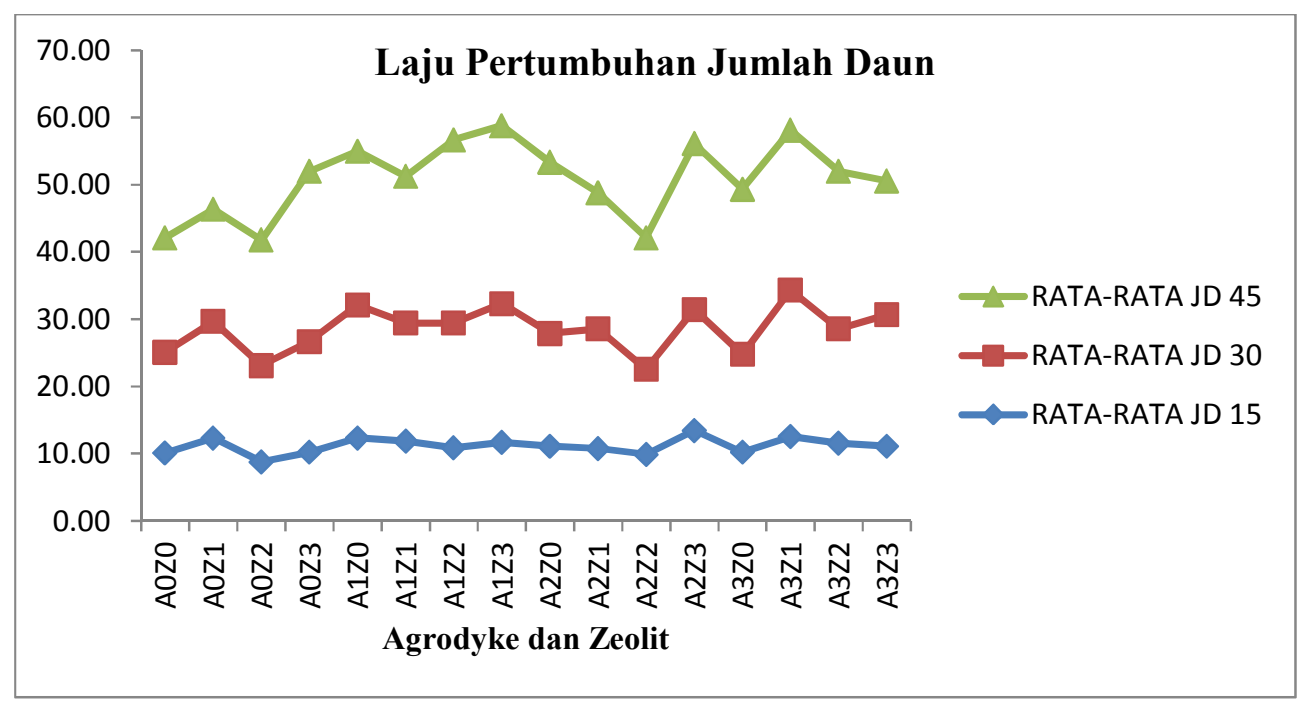

Gambar 4. Laju pertumbuhan jumlah daun tanaman bawang merah pada pemberian kombinasi pupuk agrodyke dan zeolit

Tabel 1. Tinggi tanaman bawang merah $45 \mathrm{Hst}$

\begin{tabular}{lcccccc}
\hline Perlakuan & \multirow{2}{*}{ Z0 } & Z1 & Z2 & Z3 & $\begin{array}{l}\text { Rata- } \\
\text { Rata }\end{array}$ & $\begin{array}{l}\text { Uji BNT } \\
0.05\end{array}$ \\
\hline A0 & $18.14^{\mathrm{cx}}$ & $18.74^{\mathrm{cx}}$ & $18.25^{\mathrm{cx}}$ & $20.36^{\mathrm{cx}}$ & 18.87 & \\
A1 & $21.53^{\mathrm{bcx}}$ & $23.33^{\mathrm{bx}}$ & $22.27^{\mathrm{bcx}}$ & $23.49^{\mathrm{bcx}}$ & 22.65 & 4.56 \\
A2 & $25.22^{\mathrm{abx}}$ & $27.80^{\mathrm{bx}}$ & $24.21^{\mathrm{bx}}$ & $25.22^{\mathrm{bx}}$ & 25.61 & \\
A3 & $28.42^{\mathrm{az}}$ & $34.45^{\mathrm{ax}}$ & $35.62^{\mathrm{ay}}$ & $41.25^{\mathrm{ax}}$ & 34.93 & \\
\hline
\end{tabular}




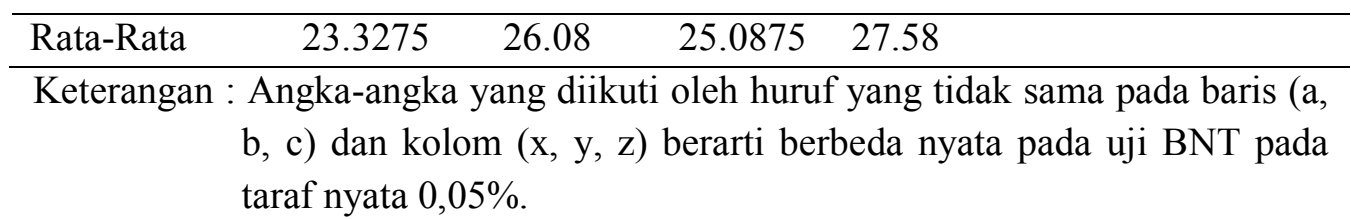

\section{Jumlah Daun}

Hasil penelitian menunjukkan bahwa perlakuan pemberian berbagai kombinasi pupuk agrodyke berpengaruh nyata sedangkan perlakuan pemberian berbagai kombinasi zeolit dan interaksi antar perlakuan pupuk agrodyke dan zeolit tidak berpengaruh nyata pada parameter jumlah daun 15 hst. Selanjutnya perlakuan pemberian berbagai kombinasi pupuk agrodyke dan perlakuan pemberian berbagai kombinasi zeolit berpengaruh nyata,

Tabel 2. Jumlah daun tanaman bawang merah $15 \mathrm{Hst}$ sedangkan interaksi antar perlakuan pupuk agrodyke dan zeolit tidak berpengaruh nyata pada parameter jumlah daun 30 hst. Kemudian perlakuan pemberian berbagai kombinasi pupuk agrodyke dan perlakuan pemberian berbagai kombinasi zeolit berpengaruh nyata sedangkan interaksi antar perlakuan pupuk agrodyke dam zeolit tidak berpengaruh nyata pada parameter jumlah daun 45 hst.

\begin{tabular}{llrrrrr}
\hline Perlakuan & Z0 & Z1 & Z2 & Z3 & $\begin{array}{l}\text { Rata- } \\
\text { RatA }\end{array}$ & $\begin{array}{l}\text { Uji BNT } \\
0.05\end{array}$ \\
\hline A0 & 8.44 & 9.09 & 10.63 & 10.33 & $9.62^{\mathrm{c}}$ & \\
A1 & 12.07 & 12.22 & 12.11 & 12.00 & $12.10^{\mathrm{b}}$ & 1.38 \\
A2 & 14.85 & 13.37 & 13.14 & 14.30 & $13.91^{\mathrm{a}}$ & \\
A3 & 13.48 & 14.00 & 14.88 & 13.29 & $13.91^{\mathrm{a}}$ & \\
\hline Rata-Rata & 12.21 & 12.17 & 12.69 & 12.48 & & \\
\hline
\end{tabular}

Keterangan : Angka-angka yang diikuti oleh huruf yang tidak sama pada baris (a, b, c) berbeda nyata pada uji BNT pada taraf nyata $0,05 \%$.

Tabel 3. Jumlah daun tanaman bawang merah 30 Hst

\begin{tabular}{lrrrrrr}
\hline Perlakuan & Z0 & Z1 & Z2 & Z3 & $\begin{array}{l}\text { Rata- } \\
\text { Rata }\end{array}$ & $\begin{array}{l}\text { Uji BNT } \\
0.05\end{array}$ \\
\hline A0 & 15.00 & 14.47 & 14.33 & 16.44 & $15.06^{\mathrm{c}}$ & \\
A1 & 22.70 & 21.78 & 22.04 & 23.70 & $22.56^{\mathrm{b}}$ & 2.37 \\
A2 & 23.85 & 22.29 & 25.66 & 27.33 & $24.79^{\mathrm{b}}$ & \\
\hline
\end{tabular}


JASc, Vol 5 No 2, November 2021

\begin{tabular}{llllll}
\hline A3 & 27.04 & 29.99 & 33.70 & 34.36 & $31.28^{\mathrm{a}}$ \\
\hline Rata-Rata & $22.15^{\mathrm{b}}$ & $22.14^{\mathrm{b}}$ & $23.94^{\mathrm{ab}}$ & $25.46^{\mathrm{a}}$ & \\
\hline
\end{tabular}

Keterangan : Angka-angka yang diikuti oleh huruf yang tidak sama pada baris (a, b, c) dan kolom berarti berbeda nyata pada uji BNT pada taraf nyata $0,05 \%$.

Tabel 4. Jumlah daun tanaman bawang merah 45 Hst

\begin{tabular}{l|rrrr|lc}
\hline Perlakuan & Z0 & Z1 & Z2 & Z3 & $\begin{array}{l}\text { Rata- } \\
\text { Rata }\end{array}$ & $\begin{array}{l}\text { Uji BNT } \\
0.05\end{array}$ \\
\hline A0 & 17.00 & 19.33 & 20.66 & 25.33 & $20.58^{\mathrm{d}}$ & \\
A1 & 22.89 & 21.77 & 28.22 & 28.72 & $25.40^{\mathrm{c}}$ & 3.55 \\
A2 & 32.63 & 29.70 & 31.30 & 41.70 & $33.84^{\mathrm{b}}$ & \\
A3 & 40.96 & 45.54 & 49.60 & 54.92 & $47.76^{\mathrm{a}}$ & \\
\hline Rata-Rata & $28.37^{\mathrm{c}}$ & $29.08^{\mathrm{bc}}$ & $32.44^{\mathrm{b}}$ & $37.66^{\mathrm{a}}$ &
\end{tabular}

Keterangan : Angka-angka yang diikuti oleh huruf yang tidak sama pada baris (a, b, c) berarti berbeda nyata pada uji BNT pada taraf nyata $0,05 \%$.

Jumlah Umbi

Hasil penelitian menunjukkan bahwa perlakuan pemberian berbagai kombinasi pupuk agrodyke berpengaruh nyata sedangkan perlakuan pemberian berbagai kombinasi zeolit dan interaksi antar perlakuan pupuk agrodyke dan zeolit tidak berpengaruh nyata pada parameter jumlah umbi.

Tabel 5. Jumlah umbi tanaman bawang merah

\begin{tabular}{llrrrrr}
\hline Perlakuan & Z0 & Z1 & Z2 & Z3 & $\begin{array}{l}\text { Rata- } \\
\text { Rata }\end{array}$ & $\begin{array}{l}\text { Uji BNT } \\
0.05\end{array}$ \\
\hline A0 & 8.44 & 8.11 & 6.89 & 9.33 & $8.19^{\mathrm{d}}$ & \\
A1 & 10.92 & 10.89 & 10.96 & 11.19 & $10.99^{\mathrm{c}}$ & 2.25 \\
A2 & 12.22 & 12.82 & 14.66 & 15.51 & $13.81^{\mathrm{b}}$ & \\
A3 & 22.22 & 17.88 & 21.59 & 21.63 & $20.84^{\mathrm{a}}$ & \\
\hline Rata-Rata & 13.45 & 12.42 & 13.52 & 14.41 & & \\
\hline
\end{tabular}

Keterangan : Angka-angka yang diikuti oleh huruf yang tidak sama pada baris (a, b, c) berbeda nyata pada uji BNT pada taraf nyata $0,05 \%$.

\section{Diameter Umbi}

Hasil penelitian menunjukkan bahwa perlakuan pemberian berbagai kombinasi pupuk agrodyke berpengaruh nyata sedangkan perlakuan pemberian berbagai kombinasi zeolit dan interaksi antar perlakuan pupuk agrodyke dan zeolit tidak berpengaruh nyata pada parameter diameter umbi. 
JASc, Vol 5 No 2, November 2021

Tabel 6. Diameter umbi tanaman bawang merah

\begin{tabular}{lrrrrrr}
\hline PERLAKUAN & Z0 & Z1 & Z2 & Z3 & $\begin{array}{l}\text { RATA- } \\
\text { RATA }\end{array}$ & $\begin{array}{l}\text { UJ BNT } \\
0.05\end{array}$ \\
\hline A0 & 19.50 & 21.11 & 17.99 & 16.76 & $18.84^{\mathrm{d}}$ & \\
A1 & 23.25 & 18.72 & 22.54 & 25.99 & $22.63^{\mathrm{c}}$ & 3.51 \\
A2 & 30.74 & 24.97 & 31.22 & 33.00 & $29.99^{\mathrm{b}}$ & \\
A3 & 39.17 & 35.22 & 38.96 & 39.71 & $38.27^{\mathrm{a}}$ & \\
\hline Rata-Rata & 28.16 & 25.00 & 27.67 & 28.86 & &
\end{tabular}

Keterangan : Angka-angka yang diikuti oleh huruf yang tidak sama pada baris (a, $b, c)$ berbeda nyata pada uji BNT pada taraf nyata $0,05 \%$.

Berat Umbi Basah

Hasil penelitian menunjukkan

bahwa perlakuan pemberian berbagai

kombinasi pupuk agrodyke

berpengaruh nyata sedangkan perlakuan pemberian berbagai kombinasi zeolit dan interaksi antar perlakuan pupuk agrodyke dan zeolit tidak berpengaruh nyata pada parameter berat umbi basah.

Tabel 7. Berat umbi basah tanaman bawang merah

\begin{tabular}{lrrrrrr}
\hline PERLAKUAN & Z0 & Z1 & Z2 & Z3 & $\begin{array}{l}\text { RATA- } \\
\text { RATA }\end{array}$ & $\begin{array}{l}\text { UJI BNT } \\
0.05\end{array}$ \\
\hline A0 & 44.55 & 47.22 & 46.33 & 55.77 & $48.47^{\mathrm{b}}$ & \\
A1 & 46.66 & 36.11 & 54.89 & 62.89 & $50.14^{\mathrm{b}}$ & 11.04 \\
A2 & 58.66 & 58.33 & 66.11 & 65.55 & $62.17^{\mathrm{a}}$ & \\
A3 & 46.44 & 65.55 & 64.55 & 70.33 & $61.72^{\mathrm{a}}$ & \\
\hline Rata-Rata & 49.07 & 51.80 & 57.97 & 63.63 & & \\
\hline
\end{tabular}

Keterangan : Angka-angka yang diikuti oleh huruf yang tidak sama pada baris (a, $b, c)$ berbeda nyata pada uji BNT pada taraf nyata $0,05 \%$.

Berat Umbi Kering

Hasil penelitian menunjukkan

bahwa perlakuan pemberian berbagai

kombinasi pupuk agrodyke

berpengaruh nyata sedangkan perlakuan pemberian berbagai

kombinasi zeolit dan interaksi antar perlakuan pupuk agrodyke dan zeolit tidak berpengaruh nyata pada parameter berat umbi kering.

Tabel 8. Berat umbi kering tanaman bawang merah

\begin{tabular}{lrrrrrr}
\hline Perlakuan & Z0 & Z1 & Z2 & Z3 & $\begin{array}{l}\text { Rata- } \\
\text { Rata }\end{array}$ & $\begin{array}{l}\text { Uji BNT } \\
0.05\end{array}$ \\
\hline A0 & 24.55 & 37.18 & 32.40 & 55.77 & $32.49^{\mathrm{b}}$ & \\
A1 & 35.18 & 27.77 & 44.37 & 62.89 & $36.39^{\mathrm{b}}$ & 8.94 \\
A2 & 50.77 & 46.85 & 58.93 & 65.55 & $53.67^{\mathrm{a}}$ & \\
A3 & 38.63 & 53.96 & 54.21 & 70.33 & $51.51^{\mathrm{a}}$ & \\
\hline
\end{tabular}


\begin{tabular}{lcccc}
\hline Rata-Rata & 37.28 & 41.44 & 47.47 & 63.63 \\
\hline Keterangan : Angka-angka yang diikuti oleh huruf yang tidak sama pada baris (a,
\end{tabular} b, c) berbeda nyata pada uji BNT pada taraf nyata $0,05 \%$.

Pembahasan

Pertumbuhan tanaman

Pertumbuhan tanaman adalah

suatu proses pada tanaman yang mengakibatkan perubahan ukuran tanaman semakin besar. Berdasarkan hasil penelitian Pada tabel 1 di atas menunjukkan bahwa perlakuan pemberian berbagai berbagai kombinasi pupuk agrodyke dan zeolit berpengaruh nyata terhadap tinggi tanaman pada umur 45 hst dan memiliki intraksi yang baik yang mana dari hasil uji lanjutan BNT $\alpha=0,05$ menunjukkan bahwa pemberian berbagai kombinasi pupuk agrodyke dan zeolit, A3Z0 (6 $\mathrm{g} / \mathrm{l}$ air + kontrol) memberikan intraksi yang baik dan berpengaruh nyata terhadap tinggi tanaman 45 hst. Tinggi tanaman bawang merah akan meningkat seiring bertambahnya umur tanaman. Pupuk organik agrodyke yang diaplikasikan dengan cara penyemprotan pada daun. Tanaman pada 45 hst telah terjadi pembentukan daun secara sempurna sehingga dapat menyerap pupuk secara optimal, hal ini sejalan dengan pendapat Hardjowigeno (1992) yang menyatakan tanaman dapat menyerap unsur hara melalui akar dan melalui daun.

Pertumbuhan suatu tanaman selain ditentukan oleh faktor genetik juga dipengaruhi oleh faktor lingkungan. Salah satu faktor lingkungan tersebut adalah suplay unsur-unsur hara, tanaman akan tumbuh dengan baik bila semua unsur hara yang dibutuhkan tersedia dalam jumlah yang cukup seimbang. Hal ini didasarkan pada kenyataan bahwa tinggi tanaman merupakan parameter yang paling mudah untuk dilihat (Lakitan 2011). Penambahan tinggi umumnya digunakan sebagai petunjuk yang memberikan ciri pertumbuhan.

Hasil penelitian pada tabel 2 yaitu pada umur tanaman 15 hst menunjukkan bahwa perlakuan A3 (6 g/l air) memberikan pengaruh yang terbaik terhadap jumlah daun tanaman bawang merah. Kemudian pada tabel 3 dan tabel 4, yaitu pada umur 30 hst dan 45 hst menunjukkan bahwa perlakuan A3 (6 g/l air) dan Z3 (12000 kg/ha) memberikan pengaruh yang terbaik terhadap jumlah daun tanaman bawang merah. 
JASc, Vol 5 No 2, November 2021

Hal ini duga disebabkan penggunan zeolit dapat meningkatkan kadar unsur hara yang terdapat didalam tanah, sehingga berperan dalam proses fisiologis tanaman, mempengaruhi perkembangan akar, dan mempertahankan mekanisme absorpsi unsur hara menyebabkan serapan unsur hara meningkat. Dengan meningkatnya kapasitas tukar kation tanah, maka nitrogen yang ada didalam tanah tidak akan mudah tercuci dan tervolatilisasi, zeolit dapat menahan nitrogen supaya tidak tercuci atau menguap. Nitrogen bahan pembentuk utama dalam klorofil yang berguna untuk proses fotosintesis. Hal ini sesuai dengan pernyataan Suyartono (2005) yang menyatakan bahwa zeolit dalam bidang pertanian digunakan sebagai pengontrol dalam pelepasan ionEion $\mathrm{NH} 4+, \mathrm{K}+$ dari pupuk yang diberikan kedalam tanah, cadangan air, penangkap logamElogam berat dari air limbah yang dipakai untuk pertanian, dan sebagai pemantap tanah. Peningkatan ketersediaan nitrogen dengan pemberian zeolit lebih terlihat pada tanah-tanah dengan kandungan unsur hara yang lebih rendah.

\section{Produksi Umbi Tanaman}

Pada produksi tanaman bawang merah dalam hal ini produksi umbi, menunjukkan bahwa pemberian berbagai kombinasi pupuk organik agrdoyke berpengaruh nyata terhadap jumlah umbi, diameter umbi, berat umbi basah dan kering bawang merah. Pada tabel 5 menunjukkan bahwa jumlah umbi terbanyak pada pemberian pupuk agrodyke dengan perlakuan A3 (6 g/1 air) memberikan pengaruh terbaik terhadap jumlah umbi yaitu 20,84 dan terendah pada perlakuan A0 (kontrol) yaitu 8,19. hal ini diduga bahwa takaran yang diberikan sudah sesuai dengan pertumbuhan dan perkembangan tanaman bawang merah. Takaran pupuk dalam pemupukan haruslah tepat, artinya tidak terlalu sedikit ataupun terlalu banyak yang dapat menyebabkan pemborosan atau dapat merusak akar tanaman. Hal ini sesuai dengan pendapat Setiadi (2008) dalam Maulidil Fajri (2014) pertumbuhan produksi tanaman dipengaruhi oleh faktor tanah/iklim dan tanaman itu sendiri yang semuanya saling berinteraksi.

Hasil penelitian pada tabel 6 menunjukkan bahwa diameter umbi 
terbesar pada pemberian pupuk agrodyke dengan perlakuan A3 (6 g/1 air) yaitu $38,27 \mathrm{~mm}$ dan terendah pada perlakuan A0 (kontrol) yaitu 18,84 mm. Hal tersebut terjadi karena kandungan unsur $\mathrm{K}$ dalam pupuk agrodyke yang tinggi mempercepat proses pembesaran umbi. Ini didukung oleh Sutrisna et al. (2003) yang menyatakan bahwa keseimbangan unsur hara terutama $\mathrm{K}$ di dalam tanah sangat berperan dalam sintesis karbohidrat dan protein sehingga sangat membantu memperbesar umbi bawang merah. Selain itu hal ini mungkin juga karena pengolahan tanah yang cukup baik sehingga tanah gembur. Kondisi tersebut mendukung dalam perkembangan besar umbi di dalam tanah, sehingga hanya sedikit umbi yang berukuran kecil. Sudjijo (1994) menyatakan pengolahan tanah yang baik menyebabkan unsur hara yang ada di dalam tanah, seperti pupuk kandang ataupun unsur hara lain akan bercampur sedemikian rupa dalam mengisi keseluruhan bagian tanah, sehingga akan berpengaruh pada perkembangan umbi.

Berat umbi basah tertinggi dengan pemberian pupuk agrodyke pada perlakuan A3 (6 g/l air) yaitu
$61,72 \mathrm{~g}$ dan terendah pada perlakuan A0 (kontrol) pada tabel 7 yaitu 48,47. Hal ini diduga karena pemberian pupuk agrodyke pada dosis tinggi mengandung zat hara yang cukup untuk menaikkan bobot umbi basah. Bobot umbi basah yang rendah kemungkinan berhubungan dengan sedikitnya pupuk agrodyke yang diperlukan tanaman sehingga pertambahan bobot umbi basah lambat. Hasil penelitian pada Tabel 8 juga menunjukkan bahwa pemberian kombinasi pupuk agrodyke pada perlakuan A2 (6 g/l air) memberikan pengaruh terbaik terhadap berat umbi kering yaitu $51,51 \mathrm{~g}$, sedangkan terendah pada perlakuan A0 (kontrol) yaitu 32,49 g. Hal ini diduga karena pengunan pupuk yang tepat/seimbang akan membantu tanaman tumbuh dan berkembang dengan baik dalam hal ini penambahan bobot umbi tanaman disamping itu ini juga sejalan dengan (Sutedjo dan Kartasapoetra dalam Muhammad Hidayatullah. 2005) yang menyatakan bahwa kalium yang tersedia di dalam tanah melalui pupuk agrodyke sudah mencukupi untuk proses umbi dan meningkatkan hasil berangkasan kering umbi tanaman bawang merah 


\section{KESIMPULAN DAN SARAN}

\section{Kesimpulan}

Berdasarkan hasil penelitian yang dilakukan dapat disimpulkan bahwa :

1. Terdapat respon terbaik pertumbuhan dan produksi tanaman bawang merah (Allium cepa L) terhadap aplikasi pemberian pupuk organik agrodyke pada dosis A2 (4 g/l air) dan A3 (6 g/l air).

2. Terdapat respon terbaik pertumbuhan dan produksi tanaman bawang merah (Allium cepa L) terhadap aplikasi pemberian zeolit pada dosis Z3 $(12000 \mathrm{~kg} / \mathrm{ha})$.

3. Terdapat intraksi kombinasi terbaik pertumbuhan dan produksi tanaman bawang merah (Allium cepa $\mathrm{L}$ ) terhadap aplikasi pemberian pupuk organik agrodyke dan zeolit pada dosis A3Z0 (6 g/l air + kontrol).

\section{DAFTAR PUSTAKA}

BPS (Badan Pusat Statistik). 2019. Statistik tanaman sayuran dan buah-buahan semusim Indonesia.
Darmia. 2011. Peranan pupuk agrodyke. Jakarta: Pertani

Hafsah, M. D. 2003. Kebijaksanaan peningkatan produksi padi melalui kegiatan peningkatan produktivitas padi terpadu. Prosiding Lokakarya Pelaksanaan Program P3T, Yogyakarta 17-18 Desember 2002.

Hardjowigeno S., 1992. Ilmu tanah. Akademi Pressindo. Jakarta

Lakitan, B. 2011. Dasar-dasar fisiologi tumbuhan. Raja Grafindo Persada. Jakarta.

Maulidil F. 2014. Pengaruh dosis pupuk kandang dan kalium terhadap pertumbuhan dan hasil tanaman bawang merah (Allium cepa L. kelompok Agregatum). Aceh Barat: Universitas Teuku Umar

Muhammad H. 2005. Respon dua varietas bawang merah (Allium ascalonicum L) terhadap imbangan pemberian pupuk organik kascing dan anorganik. Jember: Universitas Muhammadiyah

Rahayu, Mujiyo, dan Arini RU. 2018. Land suitability evaluation of shallot (Allium ascalonicum L.) at production centres in Losari District, Brebes. Journal Of Degraded Andmining Landsmanagement. 6 (1): 1505-1511

Soepardi G., 1983. Sifat dan ciri tanah. Departemen Ilmu Tanah. IPB, Bogor. 
Sudjijo. 1994. Pengaruh beberapa jenis pupuk organik terhadap pertumbuhan dan hasil wortel. J. Hort. 4(2): $38-4$.

Sutrisna, N., S. Suwalan, dan Ishaq. 2003. Uji kelayakan teknis dan finansial penggunaan pupuk npk anorganik pada tanaman kentang dataran tinggi Jawa Barat. J. Hort. 13(1):67-75.

Suyartono. 2005. Peranan kapur dan zeolit dalam pertanian. Direktorat Jendral Pertambangan Umum. Pusat Pengembangan Teknologi Mineral. Jakarta. 